\title{
Capital Structure and Business Groups: Evidence from Pakistan
}

\author{
Aamir Inam Bhutta * $\quad$ Tahir Suleman $^{\dagger}$
}

\begin{abstract}
The purpose of this study is not only to test the effects of group affiliation on capital structure decisions of Pakistani firms, but also to compare the determinants of capital structure of group's affiliated firms with those of independent firms. This study also investigates the differences in financial decision of both group affiliates and independent firms during the period of energy crisis. Using the 2-step GMM method, this study finds that business group affiliated firms use relatively more debt financing as compared to independent firms in Pakistan. Overall, this study verifies the existence of standard determinants as suggested by capital structure theories. However, practical differences exist regarding the determinants (e.g., firm size, firm growth, firm profitability and firm tangibility) between both group's affiliated firms and independent firms specially. Moreover, larger and more profitable groups are using more debt financing, while the highly leveraged and diversified groups have a limited access to debt financing.The findings also suggest a high level of accessibility to the debt financing for the group affiliates as compared to independent firms without a significant shift in the firm level determinants of capital structure during the energy crisis. It is the group's overall risk that appears to be an important attribute for the external finance providers during the energy crisis.
\end{abstract}

Keywords: Capital structure, business groups, energy crisis, and Pakistan.

\section{Introduction}

Generally, a business group is owned and controlled by a single family (Almeida \& Wolfenzon, 2006) through pyramidal structure and voting rights (Gohar, 2013). Cross-ownership and common directorship is also common features in business groups (Khanna \& Rivkin, 2001), which helps the family to control and influence on the capital structure decisions through their representatives (especially family members) sitting on the board (Paligorova \& Xu, 2012).

Emerging markets are normally characterized by weak financial markets and institutions, which make it hard for the firms to raise capital. This is one of the reasons to merge into the business groups in emerging countries (Khanna, 2000). A separate legal entity for each affiliate makes the business groups different from conglomerates. These affiliates can not only have direct access the external capital market, but also have an ability to raise funds through the internal capital market (Dewaelheyns \& Van Hulle, 2010).

On the other hand, financing decisions are taken in the headquarter in case of conglomerates and passed through to the divisions (Stein, 1997; Bianco \& Nicodano, 2006). There are differences in financing decisions of business groups and independent firms,

\footnotetext{
* Department of Banking and Finance, Government College University, Faisalabad. New Campus, Jhang Road, Pakistan.

E-mail: aamirinam@gcuf.edu.pk

${ }^{\dagger}$ School of Business, Wellington Institute of Techonology, New Zealand. E-mail: tahir.suleman@weltec.ac.nz
} 
and groups are difficult to monitor by external investors because of the group's complex structure and low transparency (Manos, Murinde, \& Green, 2007). Furthermore, business groups may have an ability to reduce group level taxes and may have a different agency conflict due to the fact that a single family controls all the affiliates either through direct or indirect ownership or through appointment of family members or friends to the key management positions (Paligorova \& Xu, 2012).

Like other emerging markets, business groups are common in Pakistan and mostly controlled by a single family through ownership or social ties. These can be differed from Indian business houses as they can own a bank. Business groups in Pakistan has grown from its roots either in manufacturing industry and now have ownership in banks (e.g., Nishat group and Ibrahim group) or in the financial industry and now have diversified into non-financial industries (e.g., JS group, Arif Habib group).

This study empirically investigates the capital structure decisions of business groups and compares them with capital structure decisions of independent firms using data of Pakistani firms listed on Karachi Stock Exchange (KSE) between 2003 to 2012. The sample period also covers the years of economic downturn in Pakistan due to the energy crisis, that significantly affected the profitability of manufacturing firms. About six percent shrinkage has been recorded in industrial production (Pasha, 2010), while significant decline in the performance of major contributed industries (e.g., Textile, metallic, nonmetallic, and papers, etc.) with respect to GDP of Pakistan has been noted. For example, the textile industry is losing its production capacity of dollar 33 million per day only in Punjab, which contains eighty percent of shares in the textile sector ${ }^{1}$. Furthermore, about 1 billion dollar export orders have been refused by the exporter and diverted from Pakistan as fear of delivery default due to skewed government policies that denied the power to export industries ${ }^{2}$. The overall economy is facing a loss of 210 billion rupees (Pasha, 2010) out of which 157 billion rupees loss belongs to the Industrial sector, while the export growth has become half in the past few years (Alter \& Syed, 2011).

Taken the twofold contribution, this study adds to the literature of the capital structure of business groups of emerging markets taken into account the case of Pakistan. The capital structure decisions of business group's affiliates depend on the group's own characteristics and their success to create the internal capital market and intragroup transactions (Dewaelheyns \& Van Hulle, 2010). Moreover, this paper tests the effects of the crisis on the financial decisions of both types of firms taken into account the views of De Jong, Kabir, and Nguyen (2008). They reported that there is sensitivity in a firm's capital structure with respect to country-specific factors, and also even within the same country. The same level of tangible assets as a collateral may have limited borrowing capacity for different firms at the time of change in country's environments.

Using the 2-step GMM method, this study finds that business groups use relatively more debt financing as compared to independent firms. These findings are consistent with the findings of J.-W. Lee, Lee, and Lee (2000) and Manos et al. (2007). This study also verifies the presence of standard theoretical capital structure determinants in Pakistan. However, there are certain differences in the application of those theories in between

\footnotetext{
${ }^{1}$ According to Business Recorder Newspaper Dated December 26, 2012.

${ }^{2}$ According to The News Newspaper Dated January 24, 2013.
} 
groups' affiliated firms and independent firms specifically, when determinants such as, (e.g., size, growth, profitability, and tangibility) are considered. Overall, larger and more profitable groups are using more debt financing, while the highly leveraged and diversified groups have a limited access to debt financing.

Importantly, the study's uniqueness is to compare the financing decisions of groups and independent firms in the industrial downturn of an economy. The findings suggest a higher level of accessibility to the debt financing for the group affiliates as compared to independent firms without a significant shift in the overall determinants of capital structure during the energy crisis period.

Surprisingly, it is the group overall risk that appears to be an important attribute for the external finance providers during the energy crisis as compared to the group's reputation at least in the case of Pakistan.

The rest of study is structured as follows: the following sections review the literature, describe the data, discuss the methodology, report the empirical results and lastly present the conclusion of the study.

\section{Literature Review}

After the seminal work of Modigliani and Miller on capital structure, a number of theories have been developed considering the market frictions such as taxes, bankruptcy cost, and information problems that can explain capital structure decisions of firms. The literature suggests three main theories of capital structure, including the pecking order theory, the trade-off theory and the agency cost theory.

According to Myers and Majluf (1984), managers keep in mind the adverse selection and asymmetric information during financing decision of firms. They identified the three available sources of financing and rank them based on adverse selection problems and used them accordingly ${ }^{3}$. They point out the pecking order hypothesis and state that a target debt ratio does not exist while firms prefer to fulfill their investment needs of first using retained earnings, followed by less risky debt, and finally risky external equity financing. Titman and Wessels (1988) support the pecking order theory considering the transaction costs associated with the different types of debt instruments. They conclude the utilization of internal debt ahead of external debt due to lower transaction costs associated with U.S.A firms.

The static tradeoff theory predicts an optimal capital structure, which maximizes the firm value. The optimal point is where the potential benefits of using debt are exactly equal to the potential cost associated with use of debt. Debt utilization creates a potential benefit of tax deductibility of interest payment to the firm which partly depends on the corporate tax rate, the level of taxable profit, and the availability of net debt tax shield (DeAngelo \& Masulis, 1980).

Based on the asymmetric information assumption, external investors view debt as a control mechanism for managers due to the commitment of interest payments (Jensen \&

\footnotetext{
${ }^{3}$ Retain earnings have no adverse selection, debt has less adverse selection and equity has more adverse selection problem.
} 
Meckling, 1976) and the use of debt financing is considered a potential vehicle to mitigate the misaligned incentives and constraints over investment by reducing free cash flow in the firm through an increase in monitoring from creditors (Paligorova \& Xu, 2012). It makes smaller the differences between external owners and managers by reducing the need of equity financing. On the hand, there are agency related costs of debt that arise due to conflict between equity and debt holders of leveraged firms. One such type of disagreement arises due to the under-investment in favorable projects and investing in risky projects.

The literature shows the empirical implications of these theories around the world. A few studies are discussed as below:

Shyam-Sunder and Myers (1999) empirically test these theories using data from 157 large USA firms and find evidence of better predictions of corporate financing behavior through pecking order theory as compared to the traditional static trade off theory. Furthermore, they report a low predictive power of debt behavior through the target adjusted model only when they are tested separately. Another study using French data supports the pecking order model as compared to market timing and static tradeoff model at the time of financing deficits (Kouki \& Said, 2011). In a study of homogeneous developed G-7 countries, (Rajan \& Zingales, 1995) find the similarity among the factors that determine the leverage in firms for all countries except the UK and Germany because of differences in their institutional settings and market control as compared to other countries. Using the opposite institutional setting to Rajan and Zingales (1995); Booth, Aivazian, DemirgucKunt, and Maksimovic (2001) use data of developing countries to analyze and compare the capital structure determinants with developed markets. They report homogeneity in variables driving the capital structure decisions of firms of both developed and developing markets. De Jong et al. (2008) challenge the assumptions of cross country equality of firms level determinants of capital structure using the data from 42 countries. They conclude that the macro economic factors such as the creditor rights protection, stock market development and GDP growth rate are significantly important factors behind the consistency among factors predicted by traditional capital structure theories.

Although, an attention has been given to financing decisions of firms around the globe after the development of modern theories of capital structure, very little awareness concerns the capital structure of business groups, which are playing significant role in the economic development of countries specifically in emerging countries. Manos et al. (2007) discuss the implications of three capital structure theories and their affiliation with business groups ${ }^{4}$. They point out that lower information asymmetries among group affiliates, better access to the external markets and policy makers (Ghemawat \& Khanna, 1998), easy access to foreign capital and technology (Khanna \& Palepu, 2000), reputation sharing (Chang \& Hong, 2000) and the internal capital market are the key factors directly linked to the pecking order theory.

Considering the static trade off theory, they point out that intragroup transactions and cross subsidization (Gohar, 2013) among the affiliates may create an alternative tax shield (Chang \& Hong, 2000). On the other hand, group affiliates can reduce their tax liability

\footnotetext{
${ }^{4}$ For the more detailed discussion on business group affiliation and capital structure theory implication, see the Manos et al. (2007) paper's page 445-447.
} 
by utilizing political contacts. The cost associated with the use of more debt is costing the financial distress which is used as a proxy of risk of default.

Normally, the large firms are considered less risky due to their operating diversification and they hold more tangible assets to support more debt. Affiliation with the group is considered as an alternative to firm diversification (Claessens, Djankov, Fan, Lang, et al., 1999). Thus, the group affiliates' profitability increases with group level diversification (Zattoni, Pedersen, \& Kumar, 2009) and reduces the expected cost of default by using each other's assets as collaterals and providing loan guarantees for each other. The findings of the Hirota (1999) support the notation that Japanese Keiretsu affiliates are likely to use more debt in their capital to develop the Keiretsu around their main bank.

Agency theory suggests debt as a device to reduce conflicts between managers and outside owners by reducing the need of external equity. However, utilizing more debt creates another type of conflict between debt and equity holders, when there is an increase in the risk of bankruptcy within firm or managers who hesitate to invest in more profitable risky projects called the "under-investment problem". These types of conflicts are not common in business group affiliates due to the ability of controlling shareholders to monitor member firms. A possible implication of agency theory of capital structure on business group is that group may reduce the conflict between insiders and outsiders through the internal capital market and by cross investing among member firms. For example, Bianco and Nicodano (2006) report on a large portion of external debt raised through holding companies and redistributed among the subsidiaries, whereas the legal related party transactions provide the insurance to the external investors in case of financial distress (Riyanto \& Toolsema, 2008). However, poor allocation of resources and inefficient investments generates high agency cost in the business group and expropriation of the wealth of other shareholders by the controlling owners (Claessens et al., 1999). Generally, it may be the complex structure of business groups which make it difficult to monitor the intragroup transaction within group affiliated firms for the minority shareholders.

Empirically, only a few studies shed light on the difference in leverage decisions between group and independent firms. One of the pioneering study is done by the J.-W. Lee et al. (2000) using the Korean data. They point out the higher leverage in Korean firms due to government's long-lasting development strategy. They also report that the debt financing is determined by the standard determinants of capital structure theories, but Chaebol firms have relatively higher leverage as compared to non-Chaebol firms. Similar results are documented by the Manos et al. (2007) for India. Their results favor the direct implication of pecking order theory within the business group due to its features such as lower information asymmetry in affiliated firms, increased access to external capital, and creation of internal market. However, the implication is not linear for the trade-off theory. A group affiliate may be able to keep the optimal capital structure through policy distortion (reduce their tax liability by utilizing political contacts) and internal business transactions (create the tax shield by moving profit from one member firm to another).

Paligorova and $\mathrm{Xu}$ (2012) documented, using data of G-7 countries, that the level of debt in pyramidal firms is sensitive to the level of shareholder legislation in the country. It means that a higher debt in pyramidal firms is associated with expropriation activities, 
while with a low level of debt in countries with strong shareholder rights. Moreover, family controlled affiliates have high levels of leverage and use of debt as a device for enhancing control or discipline, reduce the tax liability, or sharing risk. In another study, Chakraborty (2013) show that group affiliates have lower levels of leverage than independent firms in India due to fear of increase in bankruptcy risk and fear to cut down capital requirements and R\&D investments which can damage firms? long-run efficiency and competitive position.

H. Lee, Oh, and Park (2014) use the survey strategy and reports that the behavior of Korean CFOs is in lines of static trade-off theory prediction, but they are moderate towards pecking order at the time of security issues. The differences in tax rate between foreign and domestic markets, expected improvement in credit ratings, spread between short term and long term interest rates, and the risk of refinancing in bad times are key factors for the Korean Chaebol.

Although, the findings above suggest that emerging markets have a characteristic of practicing the standard modern theory on capital structure and theory of business groups. However, the level of debt financing depends upon the type of ownership and investor protection laws in the country. Considering the case of Pakistan, that has lower investor protection laws and a high share of family ownership. As the Pakistan economy is controlled by major business groups which have not only grown within non-banking industries, but also has a controlling ownership in banks making them more fertile to get better access to financing. Hence, the first hypothesis is stated as follows:

$H_{1}$ : There is a relatively high level of debt financing in group affiliates as compared to independent firms.

Energy plays vital role in the economic development of the country. Energy generation has a positive relationship with real GDP and real export of the Pakistan (Bashir, Nasim, Ismail, et al., 2016). The studies (Pasha, 2010; Alter \& Syed, 2011) point out a shrinkage in the economy during the energy crisis after 2007 as well as a high inflation which hurt the country's foreign exchange dependent industries more severely. A significant fall has been noted in production capacity of key industries like textile, with an increase in production cost, as a result export target missed out. Hence, these micro and macro changes not only decrease the repaying ability of the firms, but also increase the risk in the firms and force the external investors to be more careful at the time of lending. Considering the changing institutional setting, where the country specific factors significantly affect the firm specific determinants of capital structure and the utility of tangible assets become limited for borrowing within the same country (De Jong et al., 2008). The business groups are better able to emerge themselves with the changes of the financial environments (Khanna, 2000) and perform better (Zattoni et al., 2009). Using the cross country data, (Ugurlu, Altiok-Yilmaz, \& Akben-Selcuk, 2016) show that business groups have better access to the institutional loans to fulfill their capital expenditure needs, even in an economic downturn and their active internal capital markets (H. Lee et al., 2014) help to mitigate the financial constraints of their distress affiliates. The external finance providers may have relatively more confidence to lend to business groups, where they 
may be able to get more tangible guarantees to secure their investment. Especially, when the financing is negotiated from the holding company platform (Bianco \& Nicodano, 2006) and distributed among the member firms. These arguments lead to the following hypothesis:

$\mathrm{H}_{2}$ : Business group affiliates use more debt financing during the energy crisis period as compared to the independent firms.

\section{Data}

The manually collected data from annual reports are used for the period 2003 to 2012 of non-financial firms listed on the Karachi Stock Exchange. This data set allows us to analyze and compare the capital structure of business groups and independent firms before and during the energy crisis periods (started in the year 2008). Following the previous studies Khanna and Palepu (2000) and Zattoni et al. (2009), we exclude the firms joined the group during the sample period and the firms such as government and foreign firms as they have different characteristics. After, all process, the sample final sample consist of 268 firms listed on Karachi Stock Exchange.

\section{Group Identification}

Although, SECP (Securities Exchange Commission of Pakistan) provide an option to register with them as a group to attain the affiliates tax relief. However, only 22 groups register their firms ${ }^{5}$. In Pakistan, business groups are legally independent firms formulated and registered under the rules and regulations of companies ordinance 1984 and connected with each through cross-ownership, common board members, and administrative control. Two criteria were used to identify the affiliated companies. Similar to Ghani, Haroon, and Ashraf (2010), we start the group identification with the visit of the website of the group of companies where they have mentioned their associate companies. Second, we reviewed the annual reports to cross check the affiliation. We relied on two information from the annual report. First, we analysis the company information and pattern of shareholding to judge the interlocking, and ownership. A company can invest in another company through the directors and holding companies. Second, we cross-checked the information from associated company' balance sheet under other investments footnotes. We identified a firm as group affiliates, if a firm has significant direct and indirect ownership in another firm and control on the firm through the directors.

We considered a firm as an affiliate to a group, if the group representative is sitting on the board at any position plus it has more than $20 \%$ investment in the firm. However, we also considered the firm as an affiliate, if a group's family member or any executive, the director also has an executive director or key position like the Chairman. But, the firm is

\footnotetext{
${ }^{5}$ This information is shared by Mr. Waseem Ahmed Khan (working in SECP) via email dated 23.09.2013 upon request. He informed me that groups only registered those firms to whom they want to take tax relief.
} 
true public limited and no other party have an ownership more than $10 \%$ and the group' family has a significant direct and indirect ownership in the firm. Although, ownership is less than $20 \%$ aggregate. We also found that one firm is not a member of only one group in Pakistan. Groups also have a controlling ownership in banks, which is not a common practice in countries like other emerging markets such as India and Korea.

Overall, we identify approximately 85 groups of companies operating in Pakistan based on our data set. Out of these, 57 groups of companies have more than two listed firms on KSE and 28 groups of companies have only one listed firm during our sample period.

Our final data set is covering only listed KSE firms. Hence, our group affiliation data are covering only the listed affiliates. The majority of groups has two or more listed firms, but we identified some groups that have only one listed firm and the rest are unlisted. Finally, we identified 180 groups' affiliated firms out of a total of 268 firms and out of these, 18 firms belong to groups that have only one listed firm according to our time period.

\section{Measurements of Variables}

\section{Dependent Variables}

Vo (2017) points out that there are differences in the determinants of capital structure in emerging markets when firm leverage is measured using different proxies. To test the Vo (2017) finds also hold in Pakistan, this study uses multiple measures of leverage (Rajan \& Zingales, 1995). The first measure is a short term debt ratio (STD) which is defined as the ratio of short term debt to total assets. According to Khalid (2010), Pakistani firms are generally financed by the short term debt due to imperfect capital markets and their small size as compared to developed countries' firms. This is confirmed by the Booth et al. (2001) as the ratio of short term financing is higher in developing countries as compared to ratio of long term financing. The second measure is total debt (TD) ratio, which is defined as total debt to total assets (Chakraborty, 2013) and is a better indicator of firms' default risk at any point of time and provides a more accurate picture of past financing choices (Rajan \& Zingales, 1995).

Our last measure is long term debt (LTD) ratio, which is defined as long term debt to total assets. Here, long term debt is defined as a debt which has a maturity of more than one year.

\section{Explanatory Variables}

Studies show that some traditional variables affect the capital structure decisions of the firms, (Rajan \& Zingales, 1995) point out that size, profitability, tangibility and growth are important determinants of capital structure of firms. 


\section{Profitability}

Capital structure theories interpret the relationship between firm profitability and leverage decision differently. According to the static tradeoff theory, higher profitability of firms keeps the probability of default lower, and given access to more debt at favorable terms from external financiers. Hence, there is a positive relationship between profitability and debt. On the other hand, a negative relationship is suggested by the pecking order theory and empirical evidence (Rajan \& Zingales, 1995; J.-W. Lee et al., 2000; Khalid, 2010) support the pecking order theory views on traditional studies, and Manos et al. (2007) as well provide similar findings. Manos et al. (2007) interpret their findings to indicate that business groups are heavily relying on internal financing as compared to external. In case of Pakistan, a negative relation between group affiliates' profitability and debt is expected. The profitability is defined as profit before tax over book value of total asset (Manos et al., 2007).

\section{Tangibility}

Generally, it is suggested that the more fixed assets a firm has as a collaterals the more financing it can obtain from external financing due to a lower level of risk. Hence, the trade off theory predicts a positive relationship between firms' tangibility and leverage. Empirical studies, like Huang et al. (2006); Rajan and Zingales (1995); Khalid (2010) provide evidence in favor of the static tradeoff theory. We define tangibility as net fixed asset to total asset (Manos et al., 2007). Manos et al. (2007) argue that affiliates' leverage decisions may not directly relate to its own asset liquidity, as group affiliates are interlinked with each other through intragroup trading, debt guarantees within group or resource sharing. As a consequence, we expect that group affiliates tangibility may not be direct positively related to leverage.

\section{Size}

Trade-off theory predicts the larger the firm more diversified is its operations, and the easier it achieves economy of scale, and have more stabile profits. Hence, big firms bear less operating costs and produce more profit. They also have better assess to external financing because large firms provide more information to lenders as compared to small firms (Rajan \& Zingales, 1995). Lenders have less monitoring costs for larger firms (Jensen \& Meckling, 1976). Another interpretation is that providing more information to outside investors leads to less asymmetric information problems in large firms and encourage the equity investors to invest in these firms. Hence, the large firms may have less leverage. Empirical evidence from Rajan and Zingales (1995) and Huang et al. (2006) support this positive relationship, while Khalid (2010) finds a negative relation of size with leverage in Pakistan. A business group in Pakistan is large in size and may have better access to the equity market. As a consequence, we are expecting a negative relation between leverage and size. We define size as the natural log of assets. 


\section{Growth}

The static tradeoff theory suggests a negative relation with leverage as rapid intangibility of growth firms' asset trigger rapid loss of value in case of financial distress, while, the pecking order theory predicts an opposite relation as growing firms have more investment opportunities and their internal financing are not considered sufficient to grasp the opportunities. As a result, growing firms have to rely on debt financing, which is a cheaper source than equity. On the other hand, the moral hazard problem in growing firms creates agency problems between lenders and managers. Hence, agency theory predicts a negative relation between growth and leverage due to demand of higher premium from the lender as a fear of mis-allocating of funds to more risky projects. Empirical studies, like Khalid (2010) and Rajan and Zingales (1995), support the static tradeoff theory while Huang et al. (2006) find support for the pecking order theory. In case of group affiliates, (Manos et al., 2007) found a positive relation between growth and leverage and argued that owners may prefer to capture the growth of affiliates through external debt as compared to equity in order to maintain their control. Considering the changes in the institutional setting of Pakistan, lending to group affiliates may be risky due to cross subsidization within groups (Gohar, 2013), that is hard to monitor by the external debt providers. This leads to a negative relationship between growth and the debt for group affiliates. The growth is defined as the change in total assets.

\section{Liquidity}

Liquidity measures asset's ability to pay short term debt. A firm that easily meets its current liabilities gives a positive signal to the borrowers, hence that firm can borrow more. A positive relation is expected like in (Manos et al., 2007). We define the liquidity as current assets to current liabilities.

\section{Net debt tax shields (NTDS)}

NTDS is considered the substitute for the tax benefits of debt financing since depreciation is used as a substitute for interest payment. We define NTDS as deprecation divided by profit before depreciation, interest and tax (Manos et al., 2007) and expect a negative relationship with firm leverage. This expectation might be weak for group affiliated firms due to intra-trading and debt guarantees within groups and increases the affiliate abilities to borrow more.

\section{Volatility}

Generally, volatility refers to the variation in a firm's income, which is a measure of business risk. A higher variation indicates the lower probability of paying the bills of creditors on time, as a results bankruptcy risk increase. The lenders are normally reluctant to lend to high risky firms, so there is a negative relation between leverage and volatility (Titman \& Wessels, 1988). On the other hand, (Huang et al., 2006) report a positive relation be- 
tween volatility and leverage, when there is an increase in firms' assets subject to the variation in income.

\section{Group-level Control Variables}

Following Manos et al. (2007) and Chang and Hong (2000), we also control our model for group-level variables to test how group-level reputation and other characteristics affect the firms' ability to access the external debt. We use four group-level variables like group debt, group size, group profitability, and group diversity. Group diversity is defined as the amount of US 4 digit code industry, in which the group is operating, while the rest of the variables are the sum of the above defined variables for all group affiliates. Studies Zattoni et al. (2009); Gohar (2013) show that diversification both have negative and positive effects. If a business group that has a complex structure engaged in more risk-shifting and expropriating activities, which is difficult to monitor, this will discourage external investors. Hence a negative relationship is expected with firm leverage. On the other hand, if group diversification reduces risk and member firms share risk, then a positive relation can be expected.

Although, the sign of group diversity is not clear, we are expecting a positive relationship due to increase in market imperfection in Pakistan and industrial downturn. A Pakistani business group may share risk of non-profitable firms to save them from default and hold their reputation.

Groups with more profitability may generate more free cash flows which enhance its reputation and debt capacity. A positive relation is expected for groups having a low risk, high liquidity and more tangible assets. The larger business group provides more information and reduce agency costs due to their risk sharing activities. This encourages the equity investors to invest in group affiliates. Hence a negative relation is expecting with the group size. Finally, group debt is a direct measure of the overall risk of the group. So, a negative relation is expected with groups using more leverage.

\section{Methodology}

The equation (1) of leverage is similar to the model of Manos et al. (2007) as its explanatory variables cover the tradeoff theory, agency cost and pecking order theory.

$$
\begin{array}{r}
L_{i t}=\sum_{j=0}^{7} \alpha_{j} T V_{j i t}+\sum_{j=0}^{8} \beta_{j} T V_{j i t} * \text { Group }_{i t}+\sum_{j=1}^{4} \gamma_{j} G V_{j i t}+\sum_{j=1}^{12} \delta_{j} I N D U S T R Y_{j i t}+ \\
\sum_{j=1}^{10} \tau_{j} Y_{e a r_{j i t}}+\epsilon_{i t}
\end{array}
$$

where $L_{i t}$ represents the different measures of leverage of the firm $\mathrm{i}$ at time $\mathrm{t}$. The coefficients are $\alpha_{j}, \beta_{j}, \gamma_{j} \delta_{j}$ and $\tau_{j}$. The variable $T V_{j i t}$ represents a constant and the set standard 
determinants of capital structure (NTDS, tangibility, liquidity, profitability, size, growth and volatility of firm $\mathrm{i}$ at time t.) as defined in the above section. The $T V_{j i t} * \operatorname{Group}_{j i t}$ represents the set of interaction terms of traditional variables with group dummy, while Group $_{i t}$ defines as a dummy variable of group affiliates firm i at time t. $G V_{j i t}$ represents a four set of group-level variables (group profit, group size, group debt and group diversity) of the firm i at time t. INDUSTRY $Y_{j i}$ represents the dummy variables of 12 industries taking from financial statement analysis of joint stock companies from State bank of Pakistan and $Y_{e a r}$ jit are dummies of the year to control for fixed-time effects. Finally, $\epsilon_{i t}$ is an error term.

\section{Results}

Table 1 reports the mean values and standard deviations of TD (total debt to total assets), LTD (long-term debt to total assets), STD (short-term debt over total assets), Group (a dummy equal to one for firm affiliate with any business group, otherwise 0), ROA (EBT over total assets), NDTS (depreciation to profit adjusted with financial cost and depreciation), tangibility (net fixed assets to total assets), size (log of total assets), and growth (change in sales) Liq (current asset over current liabilities), and Vol (variation in income relative to previous year income) of all firms, the group affiliated firms and independent firms. Group affiliates are significantly more profitable and are large in size, whereas significantly have less tangible assets as compared to independent firms. There is no significant difference between the two types of firms in term of volatility, liquidity, and net debt tax shield. Overall, a group is operating in 4 industries with a $6 \%$ average profit, and $65 \%$ of debt financing.

Table 1

Descriptive Statistics

\begin{tabular}{lcccccccc}
\hline & \multicolumn{7}{c}{ All Firms } & \multicolumn{2}{c}{ Group Affiliates } & \multicolumn{2}{c}{ Independent } \\
\hline Variable & Obs & Mean & SD & Mean & SD & Mean & SD & Difference \\
\hline TD & 2454 & 0.4306 & 0.4199 & 0.4135 & 0.4276 & 0.4719 & 0.3978 & $-0.584^{* * *}$ \\
LTD & 2454 & 0.1987 & 0.2616 & 0.1843 & 0.251 & 0.2338 & 0.28287 & $-0.0495^{* * *}$ \\
STD & 2454 & 0.2327 & 0.3288 & 0.23043 & 0.3511 & 0.2383 & 0.2668 & -0.0079 \\
Group & 2460 & 0.7077 & 0.4549 & - & - & - & - & - \\
ROA & 2454 & 0.0458 & 0.1309 & 0.05718 & 0.11923 & 0.01815 & 0.1524 & $0.039^{* * *}$ \\
NDTS & 2454 & -0.4113 & 9.287 & -0.2633 & 8.818 & -0.7699 & 10.335 & 0.5066 \\
TANG & 2454 & 0.5079 & 0.213 & 0.4893 & 0.2078 & 0.5521 & 0.2193 & $-1.0414^{* * *}$ \\
Size & 2454 & 14.4628 & 1.5627 & 14.6918 & 1.4897 & 13.908 & 1.597 & $0.7838^{* * *}$ \\
Growth & 2220 & 0.2596 & 0.8792 & 0.2642 & 0.9126 & 0.2484 & 0.7932 & 0.0158 \\
Vol & 2220 & -2459 & $7.06 E+$ & -0.217 & 7.2911 & -0.3159 & 6.4897 & 0.0989 \\
Liq & 2454 & 1.4344 & 2.1388 & 1.4527 & 1.6829 & 1.3901 & 2.9665 & 0.0626 \\
Gr.ROA & 1494 & - & - & 0.0597 & 0.0965 & - & - & - \\
Gr.Size & 1494 & - & - & 16.3842 & 1.4761 & - & - & - \\
Gr.Debt & 1494 & - & - & 0.6542 & 0.2599 & - & - & - \\
Gr.Divers & 1494 & - & - & 4.1901 & 2.3253 & - & - & - \\
\hline
\end{tabular}

This table also shows that about 70 percent sample represents the group affiliates. Overall, the results of the descriptive statistics suggest a lower level of debt in group affiliates as compared to independent firms. These findings are consistent with the findings 
of Chakraborty (2013). Moreover, the differences of debt utilization are reduced between the group affiliates and independent firms during the crisis period as compared to the period before the crisis. The non-tabulated results report the difference in STD, LTD, and TD before (during) crisis as $0.0134(-0.0317),-0.063^{*}\left(-0.0371^{*}\right)$, and $-0.0948^{* * *}\left(-0.0251^{*}\right)$ respectively. These reductions in differences during the crisis suggest an integration and utilization of group resources to get more debt as compared to independent firms. These shifts support the positive impact of group affiliates to get more financing when required.

Table 2 shows the correlation between explanatory variables. The highest correlation is 0.82 between group size and group debt while the lowest correlation is 0.0001 between volatility and group size in absolute terms. Using the V.I.F test, there is no multicollinearity problem among the independent variables.

Table 2

Correlation Matrix

\begin{tabular}{|c|c|c|c|c|c|c|c|c|c|c|c|c|}
\hline & Group & ROA & NDTS & TANG & Size & Growth & Vol & Liq & Gr.ROA & Gr.Size & Gr.Debt & Gr.Diveris \\
\hline Group & 1.00 & & & & & & & & & & & \\
\hline $\mathrm{ROA}^{1}$ & 0.12 & 1.00 & & & & & & & & & & \\
\hline NDTS & 0.02 & 0.02 & 1.00 & & & & & & & & & \\
\hline TANG & -0.13 & -0.25 & -0.02 & 1.00 & & & & & & & & \\
\hline Size & 0.23 & 0.07 & 0.02 & -0.02 & 1.00 & & & & & & & \\
\hline Growth & 0.01 & 0.07 & 0 & -0.02 & 0.01 & 1.00 & & & & & & \\
\hline Vol & 0.01 & 0.1 & 0.03 & -0.02 & 0.01 & 0.06 & 1.00 & & & & & \\
\hline $\mathrm{Liq}$ & 0.01 & 0.06 & 0.01 & -0.26 & -0.1 & 0.04 & 0.03 & 1.00 & & & & \\
\hline Gr.ROA & 0.28 & 0.32 & -0.01 & -0.24 & 0.14 & 0.05 & 0.05 & 0.09 & 1.00 & & & \\
\hline Gr.Size & 0.79 & 0.11 & 0.03 & -0.11 & 0.26 & 0.01 & 0 & 0.02 & 0.38 & 1.00 & & \\
\hline Gr.Debt & 0.68 & -0.02 & 0.02 & 0.03 & 0.15 & -0.02 & -0.01 & -0.04 & 0.07 & 0.82 & 1.00 & \\
\hline Gr.Diveris & 0.57 & 0.1 & -0.01 & -0.1 & 0.22 & 0.01 & -0.02 & 0.07 & 0.27 & 0.61 & 0.39 & 1.00 \\
\hline
\end{tabular}

\section{Regression Results}

This section reports the results of the capital structure decisions of business groups and compare the capital structure decisions during the energy crisis. Three proxies of debt ratio; short-term debt to total assets (STD), long-term debt to total assets (LTD), and total debt to total assets (TD).

The estimation results of equation (1) using OLS method are biased for two main reasons. One, there is an omitted variable bias that may be correlated with the control variables as well as drive the firms leverage at the same time. Second, the presence of correlation between the error term and independent variables may also mislead the results from OLS. To control for the endogeneity problem, this study uses the two-step system GMM method proposed by Roodman (2006) as it is more efficient as compared to a one step procedure. Chakraborty (2013) proves that GMM effectively controls for unobserved firm-specific effects and endogeneity problem. Also, GMM is a better method to test the impact of business groups on capital structure decisions as compared to OLS and 'lagged' time series method.

Table 3 reports the results of the GMM regressions after controlling for the fixed industry effects and fixed time effects. To test the validity of exogeneity of the instruments, the insignificant results of Hansen and difference in Hansen tests validate the over-identification restriction and cannot reject the null hypothesis that instruments are 
valid across all models. Moreover, the test for first order serial correlation of residuals is significant for models 1 and 2, but not for the model 3. The second order serial correlation of residuals is insignificant across all three models. The similar kind of results are evident in table 4 . This indicates that model 1 and 2 are able to capture the time dynamic better than model 1.

In Table 3, there is a significant positive relation between group dummy and three leverage proxies: TD, LTD and STD at a significance level less than 0.001, 0.01 and 0.01 respectively. These findings suggest significantly more use of debt financing in group affiliates as compared to independent firms. The main findings are consistent with the findings of J.-W. Lee et al. (2000) and Manos et al. (2007), but are opposite to the findings of Chakraborty (2013). With respect to standard determinants of capital structure, considering the all firms, the profitability is significantly negatively related across all debt measures at significance level less than 0.001 . This relationship supports the pecking order view of capital structure is similar to what is found in earlier studies (Rajan \& Zingales, 1995; Khalid, 2010).

Table 3

Capital Structure and Business Group Affiliation

\begin{tabular}{|c|c|c|c|c|c|c|}
\hline \multirow[b]{2}{*}{ Group } & \multicolumn{2}{|c|}{$\begin{array}{l}\text { (1) } \\
\text { TD }\end{array}$} & \multicolumn{2}{|c|}{$\begin{array}{c}(2) \\
\text { LTD }\end{array}$} & \multicolumn{2}{|c|}{$\begin{array}{c}\text { (3) } \\
\text { STD }\end{array}$} \\
\hline & $0.718^{* * *}$ & $(0.102)$ & $0.194^{* *}$ & $(0.0683)$ & $0.341^{* *}$ & $(0.105)$ \\
\hline ROA & $-0.377^{* * *}$ & $(0.017)$ & $-0.127^{* * *}$ & $(0.012)$ & $-0.146^{* * *}$ & (0.019) \\
\hline NDTS & $0.00175^{* *}$ & $(0.0005)$ & $-0.00161^{*}$ & $(0.0007)$ & $0.00125+$ & $(0.0007)$ \\
\hline Tang & $0.329^{* * *}$ & $(0.0137)$ & $0.673^{* * *}$ & $(0.0136)$ & $-0.162^{* * *}$ & $(0.0128)$ \\
\hline Size & $0.00304^{* * *}$ & $(0.0005)$ & $0.00201^{* * *}$ & $(0.0004)$ & $0.00180^{* *}$ & $(0.0007)$ \\
\hline Growth & $0.0869^{* * *}$ & $(0.006)$ & $-0.0117^{* *}$ & $(0.004)$ & $0.0971^{* * *}$ & $(0.006)$ \\
\hline Vol & 0.0000544 & $(0.0002)$ & $0.000684^{* *}$ & $(0.0002)$ & $-0.000531^{*}$ & $(0.0002)$ \\
\hline Liq & $0.00208^{*}$ & $(0.001)$ & $0.00229^{* *}$ & $(0.0007)$ & $-0.0135^{* * *}$ & $(0.001)$ \\
\hline GROA & $0.0889^{* *}$ & $(0.0272)$ & $-0.261^{* * *}$ & $(0.0252)$ & $0.0885^{* * *}$ & $(0.0263)$ \\
\hline GNDTS & -0.00076 & $(0.0008)$ & $0.0041^{* * *}$ & $(0.0008)$ & $-0.0033^{* * *}$ & $(0.0008)$ \\
\hline GTang & $-0.188^{* * *}$ & $(0.0225)$ & $-0.540^{* * *}$ & (0.0187) & $0.430^{* * *}$ & $(0.0237)$ \\
\hline GSize & $-0.0554^{* * *}$ & $(0.006)$ & $-0.0186^{* * *}$ & $(0.003)$ & $-0.0771^{* * *}$ & $(0.005)$ \\
\hline GGrowth & $-0.0728^{* * *}$ & $(0.007)$ & -0.00296 & $(0.004)$ & $-0.112^{* * *}$ & $(0.007)$ \\
\hline GVol & 0.00011 & $(0.0003)$ & -0.00015 & $(0.0003)$ & 0.00046 & $(0.0003)$ \\
\hline GLiq & -0.00192 & $(0.002)$ & $0.0290^{* * *}$ & $(0.002)$ & -0.00413 & $(0.003)$ \\
\hline Gr.ROA & $0.177^{* * *}$ & $(0.0361)$ & $0.171^{* * *}$ & $(0.0362)$ & -0.0373 & $(0.0419)$ \\
\hline Gr.Size & $0.0477^{* * *}$ & $(0.0039)$ & $0.0319^{* * *}$ & $(0.0015)$ & $0.0491^{* * *}$ & $(0.0014)$ \\
\hline Gr.Debt & -0.0203 & $(0.0125)$ & $0.0420^{* * *}$ & $(0.008)$ & $-0.0825^{* * *}$ & $(0.0139)$ \\
\hline Gr.Divers & $-0.0583^{* * *}$ & $(0.0123)$ & $-0.0517^{* * *}$ & $(0.007)$ & -0.0089 & $(0.0115)$ \\
\hline Industry Effects & Yes & & Yes & & Yes & \\
\hline Year Effects & Yes & & Yes & & Yes & \\
\hline Constant & -0.0403 & $(0.167)$ & $-0.721+$ & $(0.373)$ & $0.413^{* *}$ & $(0.152)$ \\
\hline $\mathrm{N}$ & \multicolumn{2}{|c|}{2130} & \multicolumn{2}{|c|}{2130} & \multicolumn{2}{|c|}{2130} \\
\hline Hansen & \multicolumn{2}{|c|}{188.78} & \multicolumn{2}{|c|}{195.82} & \multicolumn{2}{|c|}{182.39} \\
\hline Diff Hansen & \multirow{2}{*}{\multicolumn{2}{|c|}{$\begin{array}{c}30.18 \\
-2.446^{*}\end{array}$}} & \multirow{2}{*}{\multicolumn{2}{|c|}{$\begin{array}{c}29.14 \\
-2296 *\end{array}$}} & \multicolumn{2}{|c|}{42.59} \\
\hline ar1 & & & & & -1.47 & \\
\hline ar2 & \multicolumn{2}{|c|}{1.237} & \multicolumn{2}{|c|}{1.012} & \multicolumn{2}{|c|}{1.02} \\
\hline
\end{tabular}

On the other hand, the coefficient of interaction terms of group and profitability (GROA) is positively significant for TD and STD $(<0.01$ and $<0.001)$, while LTD is negatively significantly related $(<0.001)$. The comparison of STD and LTD results reveals the strong evidence of the virtual capital market in Pakistani business groups when the short-term 
finance is needed. However, the group affiliates also follow the pecking order to meet its long-term needs. The interpretation of this negative relation within the group-affiliates is due to dislike of external exposure, debt covenants, and external financing (Manos et al., 2007).

Opposite coefficient signs of NDTS are reported for all firms and group interaction terms. This shows differences in behavior of group affiliated firms and independent firms with respect to tax savings ${ }^{6}$. There is a positive significant relationship among NDTS and TD, STD $(<0.01$ and $<0.1)$ while negative with LTD $(<0.05)$ when considering all firms and group affiliates but only significant for LTD and STD $(<0.001)$ respectively. Long term debt is a more appropriate measure because of its utilization in building of fixed assets on which chargeable depreciation brings the benefit of tax savings. The negative relation of NDTS and LTD suggests that groups rely on alternative means to reduce taxable profit, though intragroup transactions (Manos et al., 2007).

The coefficient of tangibility is positively related with TD and LTD significance level $(<0.001)$, while negative with the STD significance level $(<0.001)$ for independent firms. This relation is opposite and significant at the level $(<0.001)$ for group affiliates. Longterm financing is more likely affected by the level of tangibility in the firm. The significant positive relation of independent firms is consistent with agency theory point of view that firms that have more tangible assets can get more financing using them as collaterals. On the other hand, groups may involve centralized financing decisions (Stein, 1997), the group level guarantees and resource sharing within affiliates (Manos et al., 2007) which makes the tangibility of individual affiliates irrelevant to its own financing.

The size and growth are positively significant at $(<0.001)$ related to all measures which support the pecking order theory, except for LTD to whom growth is negatively significantly related at $(<0.01)$ significance level support the agency theory for independent firms. It means that managers of growing firms prefer to reduce agency costs by substituting the short-term debt with long-term debt (Titman \& Wessels, 1988). Both interaction terms (GSize and GGrowth) are significantly at $(<0.001)$ negatively related to leverage measures except for LTD with a coefficient for GGrwoth that is insignificant. These are in the line with the expectations that group affiliates financing decisions are sensitive to the performance of other affiliates as well. The large group affiliates are more likely to follow the pecking order theory to support their financial needs (at the time of growth) with cheapest internal capital market first.

The coefficient for liquidity is positive and significant for TD and LTD (0.1 and 0.01), but negatively significant (0.001) for STD for independent firms, while only positively significant relation between interaction GLiq and LTD is found in group affiliates. These findings mainly support the static trade off theory.

Lastly, volatility is only positive significant with LTD at $(<0.01)$ level, while negatively

\footnotetext{
${ }^{6}$ We can calculate the results coefficient of independent firm by subtracting the coefficients of group affiliates from the coefficients of all firms. For example, in table 3 model 1 coefficient of NDTS for all firms is $\left(0.00175^{* *}\right)$ with a standard error of $(0.0005)$ while the coefficient of GNDTS for group affilaited firms is $\left(-0.00076^{* *}\right)$ with a standard error of (0.0008) using same number of observations. The results of mean difference $t$ test reveal that the siginificant mean difference between NDTS and GNDTS is 0.00251 which is basically the coefficient of NDTS of Independent firms. Similar proceedure would be used to calculate the coefficients of determinants of independent firms.
} 
significant (0.05) with STD but only for independent firms.

The group level variables: group profitability, group debt, group size and group diversity have a significant effect on the capital structure decisions. Group size is the important variable and enter in the model with a significant positive sign at $(<0.001)$ level. It means that a large group provides more information to the investors, which discourage the risk shifting activities, and reduces the agency cost of debt. Moreover, group diversity has a significant negative relation with leverage at $(<0.001)$ level for TD and LTD because of their complex structure and more risk shifting activities.

Group debt is positive and significantly $(<0.001)$ related to LTD while negative and significant $(<0.001)$ with STD. However, it is hard to describe this positive relationship because a group with more leverage has less ability to get external financing. A partial explanation of this could be that large group-affiliated firms have large internal debt concentration as well as have used heavy bank borrowing through their important tangible assets (Dewaelheyns \& Van Hulle, 2010).

There is a significant $(<0.001)$ relation between group profitability and two leverage measures (TD and LTD) while a negative insignificant relation for STD. These findings suggest that a higher profitable group may invest more in the tangible assets which enhance the leverage capacity of affiliates firms. This is consistent with agency theory of debt.

The findings of Table 4 compare the effects of the energy crisis on capital structure of business group. The interaction term of the group and crisis (group*crisis) has a positive significant $(<0.001)$ relation with TD and STD measures, but insignificant with the LTD. On the other hand, the coefficient for the crisis dummy is negative significant for TD and STD $(<0.01$ and $<0.05)$, but insignificant and negative for LTD. Moreover, the group dummy is positively significantly related to TD, LTD and STD at $0.001,0.01,0.01$ significance levels respectively. Overall, these findings suggest that business groups are able to consume more debt financing as compared to independent firms during crisis period. It means that business groups are better able to emerge (Khanna, 2000) themselves and utilize the their abilities to get better access to the external markets (Ghemawat \& Khanna, 1998) in difficult times to raise capital with the help of group wise resources and reputation sharing (Chang \& Hong, 2000). Consistent with theory building, the negative significant relation of crisis with the three proxies suggests that it is significantly harder for independent firms to raise financing from external finance providers during the crisis period. Another reason in case of Pakistan is that independent firms in the sample used more debt before crisis, as compared to groups, which keep the independent firms less attractive for banks due to higher financial risk.

In addition, the signs of traditional variables and their interaction terms as well as the group level variables are similar to the Table 3 across all the variables. Someone may argue that the group wise reputation, and access to the external markets are not homogeneous across all the groups due to the heterogeneity of their size and diversity of operations. Hence, the risk associated with the each group is different. It means that the perception of external capital providers is not the same for all groups which might more exploit during the crisis period. To test whether there is a change in behavior of external financing regarding the group's reputation, group risk and diversity, the models are rerun with 
the addition of interaction terms of crisis and group-level variables: group profitability, group size, group debt, and group diversity. The findings (non-tabulated) verify the some notable shift in signs within group-level variables during the energy crisis as compared to before-crisis period. Group debt is negatively significant (0.001) for all models during the crisis as compared to positive significant (0.001) for TD and LTD level before the crisis. A shift from positive significant signs for TD and STD and negative insignificant for LTD to significant negative results has been noted for group profitability. Moreover, group size and group diversity become less important during energy crisis. From an external point of view, group size and group diversity, which reflect the reputation, is not an important attribute of debt financing. It is group risk attributes that are considered important during the energy crisis.

Table 4

Capital Structure During Energy Crisis

\begin{tabular}{|c|c|c|c|c|c|c|}
\hline \multirow[b]{2}{*}{ Group } & \multicolumn{2}{|c|}{$\begin{array}{c}1 \\
\text { TD }\end{array}$} & \multicolumn{2}{|c|}{$\begin{array}{c}2 \\
\text { LTD } \\
\end{array}$} & \multicolumn{2}{|c|}{$\begin{array}{c}3 \\
\text { STD } \\
\end{array}$} \\
\hline & $0.692^{* * *}$ & $(0.110)$ & $0.191^{* *}$ & $(0.0685)$ & $0.321^{* *}$ & $(0.105)$ \\
\hline Crisis & $-0.265^{* *}$ & $(0.081)$ & -0.0246 & $(0.0365)$ & $-0.107^{*}$ & $(0.0422)$ \\
\hline Group ${ }^{*}$ Crisis & $0.0729^{* * *}$ & $(0.006)$ & 0.00456 & $(0.0035)$ & $0.0575^{* * *}$ & $(0.0063)$ \\
\hline ROA & $-0.362^{* * *}$ & $(0.0179)$ & $-0.126^{* * *}$ & (0.0119) & $-0.140^{* * *}$ & $(0.0187)$ \\
\hline NDTS & $0.00194^{* *}$ & $(0.0006)$ & $-0.00160^{*}$ & $(0.0007)$ & 0.0014 & $(0.0008)$ \\
\hline Tang & $0.274^{* * *}$ & $(0.146)$ & $0.668^{* * *}$ & $(0.0138)$ & $-0.190^{* * *}$ & $(0.0136)$ \\
\hline Size & $0.00197^{* *}$ & $(0.0007)$ & $0.0019^{* * *}$ & $(0.0004)$ & $0.00155+$ & $(0.0008)$ \\
\hline Growth & $0.0861^{* * *}$ & $(0.0065)$ & $-0.0122^{* *}$ & $(0.0041)$ & $0.0966^{* * *}$ & $(0.0061)$ \\
\hline Vol & 0.000022 & $(0.0002)$ & $0.00066^{* *}$ & $(0.0002)$ & $-0.000577^{*}$ & $(0.0002)$ \\
\hline Liq & 0.00164 & $(0.0011)$ & $0.00235^{* *}$ & $(0.0007)$ & $-0.0135^{* * *}$ & $(0.0014)$ \\
\hline GROA & $0.0936^{* *}$ & $(0.0298)$ & $-0.260^{* * *}$ & $(0.0253)$ & $0.0896^{* * *}$ & $(0.0272)$ \\
\hline GNDTS & -0.00104 & $(0.0009)$ & $0.00403^{* * *}$ & $(0.0008)$ & $-0.00389^{* * *}$ & $(0.0009)$ \\
\hline GTang & $-0.138^{* * *}$ & $(0.0232)$ & $-0.537^{* * *}$ & $(0.189)$ & $0.462^{* * *}$ & $(0.0252)$ \\
\hline GSize & $-0.0574^{* * *}$ & $(0.0072)$ & $-0.0182^{* * *}$ & $(0.0034)$ & $-0.0779^{* * *}$ & $(0.0056)$ \\
\hline GGrowth & $-0.0746^{* * *}$ & $(0.0075)$ & -0.00257 & $(0.0043)$ & $-0.113^{* * *}$ & $(0.0071)$ \\
\hline GVol & 0.000446 & $(0.0003)$ & -0.000138 & $(0.0003)$ & $0.000607+$ & $(0.0003)$ \\
\hline GLiq & -0.000666 & $(0.0239)$ & $0.0286^{* * *}$ & $(0.0023)$ & -0.00381 & $(0.0031)$ \\
\hline Gr.ROA & $0.182^{* * *}$ & $(0.0392)$ & $0.174^{* * *}$ & $(0.0363)$ & 0.00656 & $(0.0434)$ \\
\hline Gr. Size & $0.0468^{* * *}$ & $(0.0035)$ & $0.0316^{* * *}$ & $(0.0015)$ & $0.0482^{* * *}$ & $(0.0015)$ \\
\hline Gr.Debt & -0.0146 & $(0.0125)$ & $0.0426^{* * *}$ & $(0.008)$ & $-0.0854^{* * *}$ & $(0.0137)$ \\
\hline Gr.Divers & $-0.0622^{* * *}$ & $(0.0123)$ & $-0.0522^{* * *}$ & $(0.007)$ & -0.00838 & $(0.0121)$ \\
\hline Industry \& Year Effects & Yes & & Yes & & Yes & \\
\hline Constant & -0.0191 & $(0.17)$ & $-0.749^{*}$ & $(0.369)$ & $0.435^{* *}$ & $(0.151)$ \\
\hline $\mathrm{N}$ & \multicolumn{2}{|c|}{2130} & \multicolumn{2}{|c|}{2130} & \multicolumn{2}{|c|}{2130} \\
\hline Hansen & \multicolumn{2}{|c|}{185.25} & \multicolumn{2}{|c|}{196.08} & \multicolumn{2}{|c|}{180.65} \\
\hline Diff Hansen & \multicolumn{2}{|c|}{28.19} & \multicolumn{2}{|c|}{29.2} & \multicolumn{2}{|c|}{39.37} \\
\hline ar1 & \multirow{2}{*}{\multicolumn{2}{|c|}{$-2.440^{*}$}} & \multicolumn{2}{|c|}{$-2.295^{*}$} & \multicolumn{2}{|c|}{-1.471} \\
\hline ar2 & & & \multicolumn{2}{|c|}{1.01} & \multicolumn{2}{|c|}{1.01} \\
\hline
\end{tabular}

Overall, group-affiliated firms are strongly following the peck order hypothesis before and during the crisis. The significance of Growth suggests that group-affiliated firms start to use more debt to fulfill their investment needs. It provides further evidence of the pecking order hypothesis.

Overall, there is no significant change in coefficient signs noted during energy crisis, but an increase in the significance levels across group-level variables like group size, group leverage, group profitability and group diversity. This indicates the existence and 
functioning of the internal market, resource sharing and risk sharing in the period of energy crisis.

\section{Conclusion}

This study contributes to the growing literature on business group affiliation and the firm's capital structure decisions using data for 268 firms from Pakistan for the period 2003-2012. The ten year sample not only allows to test the impact of group affiliation on capital structure decisions, but also, helps to analyze the behavior of both group affiliated firms and independent firms during the energy crisis. Previous studies documented that leverage decisions of firms are simultaneously determined by its own previous year debt financing causing the misleading results when using static models (Chakraborty, 2013) and the dynamic (two-step GMM) model is a better model to examine the impact of group affiliation on leverage.

Overall, the study indicates that affiliation with a business group has significantly positive effects on capital structure decisions of Pakistani firms across all proxies used in the study. These findings are similar to the findings of other researchers (J.-W. Lee et al., 2000; Manos et al., 2007) that business groups are using a relatively higher level of debt financing, and standard determinants of capital structure are different in group affiliates and independent firms.

There are several notable differences in determinants of capital structure decisions of both group affiliates and independent firms like in Manos et al. (2007). For example, in case of firm size, large independent firms are viewed as more diversified and may reduce their direct bankruptcy costs (J.-W. Lee et al., 2000) supporting the agency theory, while negative significant relation in case of group affiliates seems to be due to their policy distortion and resource sharing views (Manos et al., 2007) support the pecking order theory. In the case of growth, independent firms rejects the agency cost hypothesis with shortterm debt and total debt proxies as compared to group affiliates where the agency cost theory is accepted in case of long-term debt as compared to group affiliates where LTD has an insignificant relation to growth. In terms of profitability, independent firms follow the pecking order behavior which indicates the reduction of transaction costs across all the proxies, but this relation is only true for long-term financing for group affiliates. It means group affiliates don't like to external exposure, to debt restriction, and to external interference (Manos et al., 2007) as majority of groups are controlled by a single family in Pakistan. Other important findings are in terms of tangible assets relationship with debt financing. A positive relationship of tangibility with long-term debt in independent firms supports the static tradeoff theory similar to Khalid (2010), while a significant negative relation of tangibility with TD and LTD indicates that the financial decisions of group affiliates are not directly linked to its own asset liquidity.

As far as overall group variables are concerned, the group size and group profitability appear to be an important factors in capital structure decisions for affiliated firms. It means that affiliates of larger and more profitable business groups have better access to the external financing due to their good reputation in the market. Moreover, a higher 
group-level debt may not be able to limit the long-term debt financing of the group affiliates. As, the majority of groups in Pakistan is owned by a single family who have a good relationship with financial institutions and have good political connections which help them to acquire financing easily ${ }^{7}$.

Finally, the findings state that the interaction terms of group ${ }^{*}$ crisis has a positive impact on debt financing while the crisis dummy has a negative significant effect on debt proxies. These findings support the arguments about the group's ability to emerge (Khanna, 2000), and to better access the external financing (Ghemawat \& Khanna, 1998) through resource and reputation sharing (Chang \& Hong, 2000) especially during the crisis period. Moreover, the findings suggest that it is the group overall risk that becomes an important attribute for the external finance providers during the energy crisis as compared to the group's reputation at least in the case of Pakistan.

\footnotetext{
${ }^{7}$ Some of them owned banks like Nishat group have a control of MCB, Ibrahim have a control of Allied bank etc.
} 


\section{References}

Almeida, H., \& Wolfenzon, D. (2006). Should business groups be dismantled? the equilibrium costs of efficient internal capital markets. Journal of Financial Economics, 79(1), 99-144.

Alter, N., \& Syed, S. H. (2011). An empirical analysis of electricity demand in Pakistan. International Journal of Energy Economics and Policy, 1(4), 116-139.

Bashir, F., Nasim, I., Ismail, A., et al. (2016). Electricity generation and its impact on real GDP and real exports of Pakistan: A co-integration analysis. Journal of Management Sciences, 3(1), 52-67.

Bianco, M., \& Nicodano, G. (2006). Pyramidal groups and debt. European Economic Review, 50(4), 937-961.

Booth, L., Aivazian, V., Demirguc-Kunt, A., \& Maksimovic, V. (2001). Capital structures in developing countries. The Journal of Finance, 56(1), 87-130.

Chakraborty, I. (2013). Does capital structure depend on group affiliation? An analysis of Indian firms. Journal of Policy Modeling, 35(1), 110-120.

Chang, S. J., \& Hong, J. (2000). Economic performance of group-affiliated companies in Korea: Intragroup resource sharing and internal business transactions. Academy of Management Journal, 43(3), 429-448.

Claessens, S., Djankov, S., Fan, J. P., Lang, L. H., et al. (1999). Expropriation of minority shareholders: Evidence from East Asia. World Bank Washington, DC.

DeAngelo, H., \& Masulis, R. W. (1980). Optimal capital structure under corporate and personal taxation. Journal of Financial Economics, 8(1), 3-29.

De Jong, A., Kabir, R., \& Nguyen, T. T. (2008). Capital structure around the world: The roles of firm-and country-specific determinants. Journal of Banking $\mathcal{E}$ Finance, 32(9), 1954-1969.

Dewaelheyns, N., \& Van Hulle, C. (2010). Internal capital markets and capital structure: Bank versus internal debt. European Financial Management, 16(3), 345-373.

Ghani, W., Haroon, O., \& Ashraf, M. J. (2010). Business groups' financial performance: Evidence from Pakistan. Global Journal of Business Research, 5(1), 27-39.

Ghemawat, P., \& Khanna, T. (1998). The nature of diversified business groups: A research design and two case studies. The Journal of Industrial Economics, 46(1), 35-61.

Gohar, R. (2013). Cross subsidization and its effect on Pakistani business group's affiliated firm performance. Journal of Applied Finance and Banking, 3(3), 207-217.

Hirota, S. (1999). Are corporate financing decisions different in Japan? An empirical study on capital structure. Journal of the Japanese and International Economies, 13(3), 201-229.

Huang, G., et al. (2006). The determinants of capital structure: Evidence from China. China Economic Review, 17(1), 14-36.

Jensen, M. C., \& Meckling, W. H. (1976). Theory of the firm: Managerial behavior, agency costs and ownership structure. Journal of Financial Economics, 3(4), 305-360.

Khalid, S. (2010). Financial reforms and dynamics of capital structure choice: A case of publically listed firms of Pakistan. Journal of Management Research, 3(1), 1-16. 
Khanna, T. (2000). Business groups and social welfare in emerging markets: Existing evidence and unanswered questions. European Economic Review, 44(4), 748-761.

Khanna, T., \& Palepu, K. (2000). Is group affiliation profitable in emerging markets? An analysis of diversified Indian business groups. The Journal of Finance, 55(2), 867-891.

Khanna, T., \& Rivkin, J. W. (2001). Estimating the performance effects of business groups in emerging markets. Strategic Management Journal, 22(1), 45-74.

Kouki, M., \& Said, H. B. (2011). Capital structure determinants: New evidence from French panel data. International Journal of Business and Management, 7(1), 214-229.

Lee, H., Oh, S., \& Park, K. (2014). How do capital structure policies of emerging markets differ from those of developed economies? Survey evidence from Korea. Emerging Markets Finance and Trade, 50(2), 34-72.

Lee, J.-W., Lee, Y. S., \& Lee, B.-S. (2000). The determination of corporate debt in Korea. Asian Economic Journal, 14(4), 333-356.

Manos, R., Murinde, V., \& Green, C. J. (2007). Leverage and business groups: Evidence from indian firms. Journal of Economics and Business, 59(5), 443-465.

Myers, S. C., \& Majluf, N. S. (1984). Corporate financing and investment decisions when firms have information that investors do not have. Journal of Financial Economics, 13(2), 187-221.

Paligorova, T., \& Xu, Z. (2012). Complex ownership and capital structure. Journal of Corporate Finance, 18(4), 701-716.

Pasha, A. G. (2010). Economic cost of power outages. Working Paper.

Rajan, R. G., \& Zingales, L. (1995). What do we know about capital structure? Some evidence from international data. The Journal of Finance, 50(5), 1421-1460.

Riyanto, Y. E., \& Toolsema, L. A. (2008). Tunneling and propping: A justification for pyramidal ownership. Journal of Banking E Finance, 32(10), 2178-2187.

Roodman, D. (2006). How to do xtabond2: An introduction to difference and system GMM in Stata. The Stata Journal, 9, 86-136.

Shyam-Sunder, L., \& Myers, S. C. (1999). Testing static tradeoff against pecking order models of capital structure. Journal of Financial Economics, 51(2), 219-244.

Stein, J. C. (1997). Internal capital markets and the competition for corporate resources. The Journal of Finance, 52(1), 111-133.

Titman, S., \& Wessels, R. (1988). The determinants of capital structure choice. The Journal of finance, 43(1), 1-19.

Ugurlu, M., Altiok-Yilmaz, A., \& Akben-Selcuk, E. (2016). Corporate financial constraints and internal capital markets: Evidence from emerging countries. Accounting and Finance Research, 6(1), 25-42.

Vo, X. V. (2017). Determinants of capital structure in emerging markets: Evidence from Vietnam. Research in International Business and Finance, 40, 105-113.

Zattoni, A., Pedersen, T., \& Kumar, V. (2009). The performance of group-affiliated firms during institutional transition: A longitudinal study of Indian firms. Corporate Governance: An International Review, 17(4), 510-523. 